UNIVERSIDADE DE BRASÍLIA

CENTRO DE EXCELÊNCIA EM TURISMO

\title{
Parque Ecológico de Uso Múltiplo Olhos D’Água: \\ situação atual e importância para o lazer da comunidade
}

Gustavo Henrique Gomes

Orientadora: Dóris Santos de Faria

Monografia de Pós-Graduação em Ecoturismo

Brasília - DF: 2004 
UNIVERSIDADE DE BRASÍLIA

CENTRO DE EXCELÊNCIA EM TURISMO

\title{
Parque Ecológico de Uso Múltiplo Olhos D’Água: \\ situação atual e importância para o lazer da comunidade
}

\author{
Gustavo Henrique Gomes
}

Monografia submetida ao CET - Centro de Excelência em Turismo da Universidade de Brasília, como parte dos requisitos necessários para a obtenção de Especialização em Ecoturismo.

Aprovado por:

Brasília - DF: 2004 


\section{RESUMO}

A destinação de áreas naturais à conservação ambiental é uma idéia antiga na história da humanidade, e já era posta em prática por civilizações como a dos assírios. O conceito moderno de Área Protegida começaria a surgir na Europa, durante o século XIX. com os "parques naturais" franceses, e as "reservas da natureza" inglesas. O Parque Ecológico de Uso Múltiplo Olhos D Água é uma Área Protegida, localizada no Distrito Federal, nas Superquadras 413/414 Norte, que está hoje, após alguns anos de abandono por parte do Poder Público, estabelecida como área de lazer para a população do Distrito Federal, e em particular da Asa Norte. A conclusão deste trabalho, é que, apesar de contar com infra estrutura adequada para a visitação pública, o parque possui um potencial para o desenvolvimento de projetos de educação ambiental que permanece subaproveitado. 


\section{Sumário}

1. Introdução 01

2. Referencial Conceitual 03

3. Áreas Protegidas - Breve Histórico 06

3.1. Como Surgiram as Áreas Protegidas no Mundo 06

3.2. O Surgimento das Áreas Protegidas no Brasil 07

4. Parque Ecológico de Uso Múltiplo Olhos D’Água:

$\begin{array}{ll}\text { Características } & 10\end{array}$

$\begin{array}{ll}\text { 4.1. Hidrologia } & 10\end{array}$

$\begin{array}{ll}\text { 4.2. Solos } & 10\end{array}$

$\begin{array}{ll}4.3 \text { Vegetação } & 11\end{array}$

$\begin{array}{ll}\text { 4.4 Flora } & 11\end{array}$

$\begin{array}{ll}4.5 \text { Fauna } & 13\end{array}$

$\begin{array}{ll}\text { 4.6.Trilhas } & 16\end{array}$

$\begin{array}{ll}\text { 4.7 Equipamentos } & 17\end{array}$

5.Histórico do Parque Olhos D’Água 19

$\begin{array}{ll}\text { 6. A S.A.P.O } & 25\end{array}$

7. Um indicador da Relação da Comunidade com

o Parque Olhos D'Água em 1996

8. Um indicador da Percepção dos

Freqüentadores do Parque em $2001 \quad 36$

9. A Situação Atual do Parque Olhos D'Água 40

10. Conclusão 48

11. Referencial Bibliográfico $\quad 50$

ANEXO 01 Questionário 
ANEXO 02 Fotos do Parque Olhos D'Água 


\section{Introdução}

Tendo sido criado em 1994, o Parque Ecológico de Uso Múltiplo Olhos D’Água nasceu a partir da demanda de moradores da asa norte de Brasília, em especial da SQN 415 Norte, pela implantação de um parque na área da SQN 413/414. Esta demanda, e o maior envolvimento da comunidade circunvizinha ao parque, tiveram início com a S.A.P.O (Associação dos Amigos Protetores do Parque Olhos D’Água), ONG criada a partir de iniciativa de moradores da própria SQN 415.

Desabitada, a área pública que viria a abrigar o parque sempre estivera abandonada pelo GDF, e, tendo abundância de recursos hídricos, foi alvo de diversas invasões ao longo dos anos, que Ihe trouxeram degradação ambiental.

A implantação do parque serviria então, para conservar os recursos naturais da área, além de proporcionar, à comunidade, um espaço onde pudessem ser desenvolvidas, desde atividades de lazer, até projetos de educação ambiental.

A relação entre estes elementos, lazer, educação e conservação ambiental, não é incompatível, e pode haver entre eles, uma comunhão. Segundo Barros \& Dines, 2000, a respeito de Áreas Protegidas:

" devemos considerar que a percepção adequada do lugar cria vínculos, um senso de responsabilidade, que pode transformar cada visitante em mais um aliado na causa da conservação da natureza. Sem visitantes, ou seja sem pressão popular, é difícil sensibilizar, a classe política para a aprovação de leis que dêem suporte a essas áreas e que possibilitem a obtenção de recursos financeiros, seja através do poder público, de instituições internacionais ou de particulares". 
Este trabalho busca compreender como, ao longo dos anos, têm desenvolvido-se a relação da comunidade com o Parque Olhos D’Água, como se deu sua mudança de percepção em relação ao mesmo, mudança esta, relativa às melhorias de infra-estrutura ocorridas dentro do próprio parque, e qual a importância deste para a população do Distrito Federal, em termos ambientais educacionais e recreativos. 


\section{Referencial Conceitual.}

Serão abordados, neste item, os principais conceitos envolvidos neste trabalho. Como o tema deste trabalho é um Parque Ecológico, uma área destinada à proteção ambiental, é relevante trazer aqui o conceito de Área Protegida, que é assim definida pela IUCN:

"superfície de terra e/ou de água especialmente consagrada à proteção e à manutenção da diversidade biológica, assim como dos recursos naturais e os recursos culturais associados, e manejada através de meios jurídicos ou outros meios eficazes" (IUCN, The World Conservacion Union,1994).

Para a melhor compreensão do conceito acima, é útil lembrar que, para o IBAMA (Instituto Brasileiro do Meio Ambiente e dos Recursos Naturais Renováveis), Diversidade biológica é:

"a variedade de genótipos, espécies, populações, comunidades, ecossistemas e processos ecológicos existentes em uma determinada região. Isto significa a variabilidade de organismos vivos de todas as origens, compreendendo, dentre outros, os ecossistemas terrestres, marinhos e outros sistemas aquáticos e os complexos ecológicos de que fazem parte; compreendendo ainda a diversidade dentro de espécies, entre espécies e ecossistemas" (IBAMA,1999).

Já ecossistema é definido como:

"um complexo dinâmico de comunidades vegetais,animais e de microrganismos e o seu meio inorgânico, que interagem como uma unidade funcional" (Ibid,1999).

Tratando de conservação ambiental, para a Secretaria do Meio Ambiente do Estado de São Paulo 
"conservação diz respeito a formas racionais de apropriação dos recursos naturais, baseada na continuidade dessa mesma apropriação e na manutenção ou mínima interferência nas condições ambientais" (Secretaria do Meio Ambiente do Estado de São Paulo,Diretrizes Para uma Política Estadual de Ecoturismo, 1997 p.30).

Parte crucial deste trabalho é a analise da participação da comunidade local ao Parque Olhos D'Água em sua implementação e gestão. Comunidade Local, para Marshall é :

"o conjunto particularmente constituído de relacionamentos sociais baseados em algo que os indivíduos possuem em comum - geralmente um senso comum de identidade" (Marshall,1994 in Wearing \& Neil, 2000 p.227).

Uma das finalidades de um Parque Ecológico de Uso Múltiplo é a educação ambiental dos visitantes. Educação ambiental é definida pela WWF-Brasil como:

"dimensão dada ao conteúdo e à prática da educação, orientada para a resolução dos problemas concretos do meio ambiente por meio de enfoques interdisciplinares e de uma participação ativa e responsável de cada indivíduo e da coletividade. Se caracteriza por as dimensões sócio-econômica, política, cultural e histórica. Deve permitir a compreensão da natureza complexa do meio ambiente e interpretar a interdependência entre os diversos elementos que conformam o ambiente, com vistas a utilizar racionalmente os recursos do meio na satisfação material e espiritual da sociedade no presente e futuro".(Manual de Ecoturismo de Base Comunitária, WWF-Brasil, 2003 p.430).

Já para Viezzer \& Ovalles, ela é:

"um processo de aprendizagem permanente baseado no respeito a todas as formas de vida. Tal educação afirma valores e ações que contribuem para a transformação humana e social, e para a preservação ecológica. Ela estimula a formação de sociedades socialmente justas e ecologicamente equilibradas, que conservem entre si uma relação de interdependência $e$ diversidade. Isso requer responsabilidade individual e coletiva a nível local, nacional e planetário. A educação ambiental deve gerar, com urgência, mudanças na qualidade de vida e maior 
consciência de conduta pessoal, assim como harmonia entre os seras humanos, e destes com outras formas de vida" (Viezzer \& Ovalles,1994 in Barros \& Dines, 2000 p.89).

Por fim, Parque Ecológico e de Uso Múltiplo é:

"Unidade de Conservação, que objetiva a proteção de atributos naturais junto a áreas urbanas, com finalidades educacionais, recreativas e científicas" (Governo do Distrito Federal, Lei Complementar $n^{\circ}$ 265,1999). 


\section{3. Áreas Protegidas - Breve Histórico}

\subsection{Como Surgiram As Áreas Protegidas no Mundo}

A idéia de conservar áreas naturais, e que algumas áreas possuem características especiais e por isso devem ser protegidas não é nova, e já era posta em prática por civilizações antigas, como os assírios. A proteção destas áreas poderia ser motivada pelo fato destas abrigarem recursos naturais importantes para a sobrevivência daquelas civilizações, tais como água, fontes de alimentação, plantas medicinais, ou, por estarem associadas a acontecimentos históricos marcantes, mitos, lendas, rituais religiosos, por terem, enfim, um valor simbólico. $\mathrm{O}$ acesso a estas áreas era restrito e controlado.

Na Europa Medieval surgiria a palavra "parque", que servia para nomear áreas pertencentes aos reis, nas quais viviam animais. Invasores e caçadores que entrassem nestas áreas eram condenados a morte (Runte 1997, in, Morsselo, 2000). Há ainda, como exemplos de preocupações conservacionistas, a civilização Inca, que impunha limites sazonais e territoriais à caça de determinadas espécies, e a Índia, que começou a desenvolver seus programas de áreas protegidas a mais de cem anos atrás (West, 1992 in Morsselo 2000).

No século XIX, ainda no continente europeu surgiriam conceitos novos de Áreas Protegidas. Embora séculos de intervenção humana já houvessem modificado consideravelmente os ambientes naturais europeus, começou a existir uma crescente preocupação a respeito da degradação ambiental, causada principalmente pelo crescimento urbano e pela prática da agricultura.

Esta preocupação era muito mais relativa à conservação da beleza cênica dos atributos naturais do que a uma consciência a respeito da importância da conservação da biodiversidade destes atributos. 
$\mathrm{Na}$ França, surgiu então um modelo de Área Protegida que ficaria conhecido como "Parque Natural". Como existiam poucas áreas de domínio público, e a desapropriação de terras para o estabelecimento de área de proteção ambiental seria bastante onerosa para o estado, este modelo foi baseado no regulamento do uso de propriedades privadas.

Assim, os proprietários assinavam contratos comprometendo-se a regular o uso do solo, conservar os atributos cênicos e biológicos existentes em suas propriedades, e ainda, comprometiam-se a manter trilhas nestas propriedades, para que os pedestres pudessem caminhar e apreciar a paisagem ${ }^{1}$.

Na Inglaterra surgiu também um modelo de área protegida, este elaborado a partir de iniciativa da sociedade civil, visando conservar o ambiente natural contra as transformações ocorridas pela urbanização acelerada e o processo de industrialização pelo qual passava o país, foram criadas "reservas da natureza".

No final do século XIX, paralelamente ao modelo de área protegida criado na Inglaterra, surgiria nos Estados Unidos o conceito moderno de Unidade de Conservação, com a criação do Parque Nacional de Yellowstone, em Montana, em 1872. Criado também a partir de iniciativa da sociedade civil, o conceito de "Parque Nacional", tinha por base a democratização do espaço, assegurando a todo cidadão, independente de sua classe social, o direito de acesso a uma área natural, onde pudessem ser desenvolvidas atividades de lazer e conservados os ecossistemas da região, para as gerações futuras.

\subsection{O Surgimento das Áreas Protegidas no Brasil.}

A criação dos parques nacionais norte-americanos acabou servindo com inspiração para que o engenheiro André Rebouças publicasse, em 1876, um

\footnotetext{
${ }^{1}$ Fonte: Site do Ministério do Meio Ambiente do Brasil.ww.mma.gov.br
} 
trabalho de 112 páginas, no qual propunha a criação de dois parques nacionais no Brasil. Um, o Parque Nacional de Guaíra, seria localizado em Sete Quedas e Iguaçu. O outro parque, abrangeria a llha do Bananal, hoje parte do estado do Tocantins.

A iniciativa do engenheiro foi pioneira, tendo sido a primeira proposta elaborada, visando à criação de Áreas Protegidas no Brasil. O esforço de Rebouças acabaria sendo recompensado, e as Unidades de Conservação acabariam sendo criadas, porém, vários anos após a publicação de sua proposta.

Em 1911, o cientista Luiz Felipe Gonzaga de Campos publicou trabalho intitulado "Mapa Florestal do Brasil". Neste trabalho, Campos descrevia detalhadamente as características dos ecossistemas brasileiros, assim como o estado de conservação em que cada um destes se encontrava.

A consequência da iniciativa de Campos, que tinha por finalidade também incentivar a criação de Áreas Protegidas no país, foi à publicação de Decreto Lei, assinado pelo então Presidente da República Hermes da Fonseca, ainda em 1911, que instituía uma Reserva Florestal, com 2,8 milhões de hectares, no estado do Acre. A reserva, porém, nunca foi de fato implementada, tendo sido a maior parte de sua área, completamente degradada ao longo dos anos. A pequena parte que se manteve preservada, encontra-se hoje inserida na Estação Ecológica do Rio Acre (Costa,2000).

A primeira Área Protegida brasileira surgiu, de fato, apenas no ano de 1937, com a criação do Parque Nacional de Itatiaia no estado do Rio de Janeiro . Inspirado no modelo de parques nacionais norte-americanos, Itatiaia possuía paisagem impressionante, com suas formações rochosas únicas, sendo assim atraente à visitação pública. Embora a questão da beleza cênica, fosse primordial, o decreto de criação do parque ressaltava também a importância de sua conservação biológica. Em 1939 foram criados os parques nacionais de Serra dos 
Órgãos, também próximo a então capital Rio de Janeiro, e o de Iguaçu, localizado no estado do Paraná.

A política de Áreas Protegidas brasileiras só começaria a modificar-se a partir da década de 50. Como a urbanização e ocupação do Centro-Oeste brasileiro trouxeram acentuada degradação ambiental a biomas como o Cerrado e Pantanal, passa a haver, a partir de então, uma maior preocupação com relação à conservação de ecossistemas ameaçados. Repete-se, ainda, entre o final desta década e início da posterior, o ocorrido nos anos 30, e são criadas Unidades de Conservação próximas à capital, agora Brasília, como os Parques da Chapada do Veadeiros e o das Emas em Goiás. É criado também o Parque Nacional de Brasília (Morsello,2000).

A partir dos anos 60, inicia-se a proliferação da criação de Unidades de Conservação no Brasil, porém apenas em 1975 a questão começaria a ser de fato aprofundada, com a publicação de documento do IBDF intitulado "Projeto de Implantação e Consolidação de Parques Nacionais, Reservas Equivalentes e Proteção à Natureza. Este documento diagnosticava, de maneira altamente técnica, o estado de precariedade em que se encontrava o sistema nacional de Unidades de Conservação brasileiro e fazia um mapeamento, agora de maneira criteriosa, de áreas que poderiam abrigar novas Unidades de Conservação no país. (Ibid,2000). 


\section{Parque Ecológico de Uso Múltiplo Olhos D’Água: características}

\subsection{Hidrologia}

Entre as principais características do Parque Olhos D’Água estão, a presença de nascentes (ANEXO 02, fotos 01 e 02). dentro de seus limites, além de um córrego que atravessa o parque no sentido oeste/leste. O talvegue do córrego encontra-se definido geomorfologicamente na SQN 413. A segunda cabeceira encontra-se na SQN 414.

Há ainda a Lagoa do Sapo (fotos 03,04,05), situada abaixo da Mata Mesofítica, no nordesta do parque. O local era, originalmente fluxo natural de águas provenientes da nascente. A partir da construção da via $L 2$ norte, foi feita ali uma barragem, gerando assim o represamento da água.

\subsection{Solos}

Os solos predominantes no parque são ao cambissolos, embora ocorram também manchas de latossolo vermelho-escuro e hidromórfico. Estes solos possuem a seguintes características.

Cambissolos: São solos pouco desenvolvidos devido ao relevo acidentado das superfícies nas quais se desenvolvem

Latossolo Vermelho-Escuro: São solos que se desenvolvem em superfície de relevo plano ou suave ondulado, que possuem mantos de muitos metros de espessura e bem drenados.

Hidromórfico: Solos que possuem lençol freático na superfície e desenvolvem-se sob influência do excesso de umidade. 


\subsection{Vegetação}

Quanto à vegetação, encontra-se no parque:

Campo Cerrado: forma intermediária de vegetação, entre o Cerrado strictu sensu e o campo sujo. Difere-se do Cerrado strictu sensu por ser mais aberto. Ocupa a maior área do parque e sua vegetação inclui pequenos arbustos como a faveira, jacarandá do cerrado, barbatimão e bate-caixa. Há ainda a presença de eucaliptos, plantados pelo proprietário da fazenda a qual pertencia a asa norte no início de Brasília

Mata Mesofítica: ocorre em uma área íngreme, com características florestais, principalmente devido ao fato de apresentar grande densidade. É parte da vegetação do parque que foi menos degradada ao longo dos anos.

Mata de Galeria: situada ao redor do córrego, foi bastante degradada, tendo que ser recuperada com o replantio de árvores nativas.

Existe ainda um jardim experimental, de plantas nativas do cerrado. Foi feito a partir do salvamento de plantas de áreas que seriam destruídas, mas que foram foram plantadas no parque, para além de cumprirem uma função estética, pudessem ter perpetuação garantida.

\subsection{Flora}

As principais espécies encontradas no parque foram:

Pau-jacaré (Piptadenia gonoactha): planta de rápido crescimento, é fundamental em reflorestamentos mistos destinados à recomposição de áreas 
degradadas. Possui entre 10 a 20 metros de altura. Pode ser utilizada em acabamentos internos, armações de móveis e miolos de portas.

Embaúba (Cecrópia pachystachia): planta nativa do cerrado, é característica de solos úmidos, beira de rios, córregos, brejos e lagoas. Possui de 4 a 7 metros de altura.Seus frutos são procurados por muitas espécies de pássaros. Sua madeira é leve e de baixa durabilidade natural, podendo ser utilizada em confecção de brinquedos e caixotaria leve, por exemplo.

Copaíba (Copaifera langsdorffi): espécie também nativa, com 10 a 15 metros de altura. Sua madeira é bastante durável, sendo utilizada na construção civil, confecção de móveis e peças torneadas, como coronhas de armas. O óleo extraído do seu tronco é terapêutico, podendo ser utilizado para impedir o crescimento do trypanosoma cruzi, protozoário causador do mal de chagas.

Além disso, testes feitos com animais e em tubos de ensaio pelo Inca ( Instituto Nacional de Câncer) do Rio de Janeiro, comprovaram o poder antitumoral do óleo de copaíba, que pode impedir o crescimento de um tipo de câncer de pele.

Barbatimão (Stryphnoderndron adstringens): possui de 4 a 5 metros de altura, sendo utilizada pela marcenaria em acabamentos internos como batentes de portas , esquadrias e também na construção civil. Sua casca têm propriedades anti-sépticas, anti-diarréicas e anti-hemorrágicas. Atua ainda no combate às afecções escorbúticas, hérnias, feridas, úlceras e corrimentos vaginais.

Pau-terra (Qualea Grandiflora): planta com altura media de 7 metros, com tronco de 30 a $40 \mathrm{~cm}$ de diâmetro. É utilizada para tablado em geral, em forros e miolos de compensados. 
Angico (Anadenantethera macrocarpa): a árvore possui entre 13 e 30 metros de altura. A madeira é de grande durabilidade, própria para a construção civil e naval, e para o uso em marcenaria e carpintaria. Apresenta rápido crescimento, podendo ser utilizada para o reflorestamento de áreas degradadas. É uma planta muito ornamental, própria para a arborização de árvores e praças.

Faveira (Dimorphandra mollis): sua altura varia de 8 a 14 metros. Sua madeira é empregada para tablado, confecção de caixas, compensados, forros, painéis, brinquedos e lenha de carvão. Sua casca é rica em tanino e costumava ser utilizada para curtir couro. A árvore possui grande adaptação em terrenos secos e pobres em nutrientes, sendo bastante boa para o plantio em áreas degradadas de preservação permanente.

Há ainda espécies exóticas oriundas diretamente de ações antrópicas, fruto das constantes invasões sofridas pela área. São elas: capim braquiaria (Braquiara $s p$ ), capim elefante (Pennisetum purpueum) e capim gordura (Mellinis minutifolia).

\subsection{Fauna}

Foram encontrados no parque mamíferos como gambá, preá e morcegos, quantidade considerável de aves, seis espécies de répteis, seis de anfíbios e duas peixes. Segundo o Guia do Parque Ecológico Olhos D’ Água, GDF, 1998, a baixa abundância de espécies pode dever-se ao fato de a área ter sido, desde a fundação de Brasília, bastante degradada.

Outro fator influente com relação à baixa abundância de espécies é o fato desta área estar também totalmente isolada de outros fragmentos de cerrado, e consequentemente, não haver migrações de outras populações para o parque, o que, caso ocorresse, propiciaria ali uma maior riqueza de espécies. 
Com relação aos mamíferos encontrados, os quirópteros (morcegos), desempenham papel ecológico importante, sendo dispersores de sementes, servindo como agentes polinizadores para algumas espécies de árvores e realizando o controle das populações de insetos.

Funcionam, portanto, como medidores da abundância de árvores frutíferas e de espécies de insetos, já que são predadores dos últimos. Existem no Distrito Federal, cerca de trinta espécies de morcegos, sendo encontradas no parque, três espécies: Glossophaga soricina, Artibeus lineatus e Platirrinus lineatus.

Outra espécie de mamífero encontrada no parque, o gambá é um exemplo interessante a ser usado para a educação ambiental, já que é um Mazurpial, e que possui características bastante distintas do restante dos mamíferos. Entre estas características, estão o curto período de gestação, e os filhotes, que são minúsculos e insipientemente desenvolvidos, completando assim seu período de desenvolvimento em uma bolsa chamada marsúpio.

Outro fato que pode ser comentado em uma palestra de educação ambiental, é que as características distintas desta espécie, fizeram-na sofrer pressões evolutivas distintas do restante dos mamíferos.

A avifauna encontrada no pode ser considerada rica, devendo-se isso ao fato de haver no parque uma área de mata mesofítica, que oferecem abrigo às aves, com sua grande cobertura arbórea, já que o dossel de suas árvores varia entre vinte e trinta metros.

Outras explicações para a abundância de espécies da avifauna e a não sobreposição de nichos, são o fato do parque estar situado perto do Lago Paranoá, que oferece às aves grande quantidade de recursos alimentares, e a riqueza de invertebrados, principalmente insetos, dentro da área do parque. 
Destaca-se, entre as espécies de aves encontradas a tesourinha (Tyranus savana), o tiziu (Volatinia Jacarina) e o papa capim (Sphorophila $s p$ ). Estas espécies são migratórias, aproveitando-se da época de chuva, pelo fato de haver então maior disponibilidade de alimentos, especialmente capim.

Existem também espécies típicas de áreas que sofreram processo intenso de antropização, como pardal (Passer domesticus), anu-preto(Crotophaga ani), bem-te-vi (Pitangus sulphuratus), quero-quero (Valenus chilensis), coruja buraqueira (Athene cunicularia), anu-branco (Guira guira ), e pássaro preto (Gnorimopsar chopi).

Quanto aos répteis, existem no parque camaleões, cobras e espécies de lagartixa verde e lagartixa preta, que têm abundância maior em áreas parcialmente degradadas e construções humanas. As espécies de cobras(corais, falsas corais e jararacas) e o camaleão, são encontradas em bordas de mata. Embora existam no parque cobras peçonhentas, vale salientar que o risco destas atacarem algum freqüentador é pequeno, já que as cobras apenas atacam quando são ameaçadas, ou eventualmente pisadas.

Ainda a respeito dos répteis, há uma espécie que também pode ser interessante do ponto de vista da educação ambiental, no que diz respeito aos tipos de pressões evolutivas as quais os animais são submetidos, que é o lagarto ápode (Ophiodes striatus).

Entre as seis espécies de anfíbios, estão os sapos da família Bufonidae, que embora raramente sejam vistos, são bastante comuns. São sapos de grande porte, que possuem glândulas atrás dos olhos chamadas glândulas, que possuem veneno. Estas glândulas, espontaneamente não lançam veneno, porém, se pressionadas podem lançar um veneno que causa uma pequena irritação. Há também a perereca (Hyla albopuntacta), que possui grande distribuição pelo parque, principalmente nas áreas que foram parcialmente degradadas. 
Quanto a ictiofauna , são encontradas espécies como lambari, guppy , carpa, curió e tilupia . O lambari é típico do cerrado, e as outras são espécies introduzidas. São encontradas ainda, na lagoa do sapo, outras espécies introduzidas, como patos e tartarugas. Segundo funcionários do parque, a administração do parque não dispõe de nenhum tipo de estudo ambiental referente aos impactos que as espécies introduzidas causam a fauna e flora locais.

\subsection{Trilhas}

Existem dois circuitos de trilhas dentro do Parque Olhos D' Água. Ambos podem ser acessados a partir da pista de cooper, à oeste da entrada principal do parque. O primeiro circuito (ANEXO 02 foto 06) atravessa o parque no sentido leste/oeste. Neste circuito pode-se ver espécies como faveira, mandiocão, barbatimão, e pau-santo. Há ainda uma grande quantidade de gramíneas exóticas como braquiara, capim gordura, e capim elefante. A trilha leva também até o córrego/talvegue (ANEXO 02 foto 07 ).

O outro circuito é conhecido como trilha "capitão da mata". Passa-se pelo parque infantil (ANEXO 02 foto 08), e adiante, entra-se na mata mesofítica, a área menos degradada do parque ao longo dos anos, e que apresenta grande beleza cênica. Já dentro da mata, chega-se ao "recanto do angico", onde pode-se avistar outras várias espécies, alem do próprio angico, como ipê, emburuçu, carrasco, guabiroba e jequitibá.

Ainda no recanto do angico há um entroncamento à esquerda para uma trilha natural denominada "trilha da lagoa" (ANEXO 02 foto 10), onde existem espécies de embaúba, jequitibá e angico branco, margeando a lagoa do sapo. 
Esta trilha chega até a nascente, e nela há também um entroncamento à esquerda, que leva a uma nova trilha onde pode-se avistar uma espécie de guapuruvu (Shizolobium Parayba), que chama a atenção por sua altura. Neste trecho, existem ainda espécies típicas, como cedro (Cedrella Fissilis), capitão da mata (Terminalea Argêntea) e angico. De volta a trilha "capitão da mata", passa-se pela lagoa do sapo e chega-se ao "bosque dos eucalipitos" onde há um entroncamento á direita, para a trilha do cerradinho, que é assim denominada por conter uma pequena faixa da cerrado.

\subsection{Equipamentos}

O Parque Olhos D’Água possui:

- Sede Administrativa (ANEXO 02 foto 11),

- Parque Infantil,

- Mirante,

- Centro de Visitantes (ANEXO 02 foto 12),

- Aparelhos de musculação e ginástica,

- Postes de iluminação,

- Bancos de madeira,

- Sanitários, 
- Bebedouros,

- Lixeiras. 


\section{Histórico do Parque Olhos D'Água²}

O Parque Olhos D’Água está localizado em uma área pertencente a uma das diversas fazendas existentes no Plano Piloto de Brasília antes da definição do quadrilátero do Distrito Federal. A partir da inauguração da nova capital federal, o local passou a ser alvo de várias ocupações, motivadas pelas diversas fontes de captação da água ali existentes.

Tendo sido criado em 1994, o Parque Ecológico de Uso Múltiplo Olhos D’Água de Brasília possui 21 hectares e está localizado entre as superquadras SQN 413/414 Norte. Entre os motivos oficiais que levaram a criação do parque, está a presença de invasões causadoras de degradação ambiental na área, principalmente por causa de constante retirada de vegetação nativa por parte dos invasores.

O parque foi então criado, a partir da idéia do desenvolvimento de uma cogestão entre a administração pública e sociedade civil, tendo como objetivo servir de modelo para a implementação de outros parques no Distrito Federal. Além disso, segundo a SEMARH, a criação do parque, tinha como outros objetivos:

- a preservação das nascentes existentes em seu interior,

- preservação e recuperação da Lagoa do Sapo,

- preservação e recuperação da Mata Ciliar,

- proteção da Bacia do Paranoá,

\footnotetext{
${ }^{2}$ Reconstituído utilizando como fontes, texto assinado pela ex -administradora do parque , Élia Batista, publicado em documento da Novacap intitulado "Projeto de Paisagismo do Parque Urbano de Olhos D Água" (S.D), e reportagens publicadas pelo jornal Correio Brasiliense.
} 
- desenvolvimento de programas de observação ecológica e pesquisa sobre os ecossistemas locais,

- criação de condições para a população usufruir em consonância com a preservação ambiental,

- desenvolvimento de atividades voltadas para a educação ambiental.

Apesar de ter sido criado em 1994, ter sua sede construída em 1995, apenas a partir de 1999 o parque começaria a ganhar a infra-estrutura que hoje dispõe. Alegando que o parque encontrava-se abandonado pela administração anterior do Governo do Distrito Federal, e que a população receava freqüenta-lo por causa da presença de mato alto, lixo, entulho, animais domésticos e marginais, o órgão responsável pela administração do parque à época, a Secretaria de Meio Ambiente e Recursos Hídricos do Distrito Federal (então, ainda SEMATEC), iniciaria um trabalho de roçagem na área, em parceria com outros órgãos governamentais como a NOVACAP (Companhia Urbanizadora da Nova Capital do Brasil ) e o SLU (Serviço de Limpeza Urbana), além do Instituto Candango de Solidariedade.

Neste ano ainda, seriam instalados hidrantes no parque, para que o corpo de bombeiros dispusesse de condições adequadas, para a contenção de possíveis incêndios na área do parque. Foram instaladas também duchas de água fria, para que os freqüentadores pudessem se refrescar, além de um centro de visitantes.

A proposta da SEMATEC, à época, tinha como objetivo otimizar o potencial do parque como objeto de lazer para a comunidade circunvizinha e da asa norte. O projeto tinha como meta, segundo órgão, a consonância com os 
anseios da comunidade, tendo sido exposto a mesma, e modelado, a fim de atender às suas expectativas.

Em dezembro de 2000, foram concluídas as obras de cercamento do perímetro do parque, com alambrados de 2 metros de altura, e a justificativa de se evitar assim a entrada de animais, e a fixação de andarilhos dentro da área. Além disso, o cercamento foi feito para embasar o Policiamento Militar Florestal em suas rondas na área.

Em 2000, porém, antes da conclusão do cercamento do parque, a continuidade das obras, e a própria sobrevida da área protegida estariam ameaçados. O IDHAB (Instituto de Desenvolvimento Habitacional do Distrito Federal), manifestou a intenção de reaver a área de trinta e quatro projeções dentro da poligonal do parque, que lhe pertenceria, para a construção de habitações nas superquadras 413/414 norte.

A intenção, que já havia sido manifestada pelo mesmo órgão em 1995, se concretizada, diminuiria sensivelmente os limites do parque. A situação fundiária do parque, aliás, era tão confusa, que havia ainda em sua área dois lotes pertencentes à PETROBRÁS, desde 1.977, e que foram vendidos à empresa estatal para a construção de dois postos de gasolina ali.

Ciente da possibilidade real de prejuízo para a área protegida, a comunidade residente em torno do parque começou a mobilizar-se. A prefeitura da SQN 415 organizou um abaixo assinado, visando à manutenção da área do parque. O movimento acabou ganhando relevância, e o GDF, pressionado, acabou decidindo atender os apelos da população. A SEMARH (nova designação da SEMATEC), então, entrou em acordo com o IDHAB, conseguindo assim manter a área sob sua responsabilidade. 
No início de 2001 foram licitadas obras para dar continuidade a implementação do parque, e tiveram início a construção de três pontes, uma com 93 metros de extensão sobre a Lagoa do Sapo (ANEXO 02 foto 13), acompanhando o talude junto ao alambrado, e duas pontes (ANEXO 02 foto14) sobre o córrego/talvegue para dar passagens aos dois lados do mesmo.

Ainda em 2001, foi construída uma pista de Cooper com dois mil e cem metros de extensão (ANEXO 02 foto15) e pavimentação asfáltica. A SEMARH justificaria o asfaltamento da pista, como uma forma de atender a Lei Distrital $\mathrm{n}^{\circ}$ 2867 de 29 de janeiro de 2001, referente ao condicionamento de acesso aos portadores de deficiências físicas, com a declividade do terreno não podendo ultrapassar a $8 \%$.

Outras justificativas para o asfaltamento da pista, seriam sua funcionalidade nas ações de prevenção de incêndios no parque e também para o acesso de policiamento a área. Além disso, havia a intenção de proporcionar ao publico que caminhava nas quadras circunvizinhas ao parque, uma melhor infraestrutura para a prática de caminhada e cooper, partido do princípio que o público não utilizaria o parque justamente pela falta desta mesma infra-estrutura. As obras foram inauguradas em 23 de setembro de 2001, e seus custos para o GDF foram de $\mathrm{R} \$ 700.000$.

A pista asfaltada foi inicialmente divida em duas mãos. Uma destinada aos pedestres e outras aos ciclistas. Em janeiro de 2002, o trafego de ciclistas seria proibido no parque. Em votação aberta ao público, realizada entre os dias 21 de dezembro de 2001 e 3 de janeiro de 2002 e organizada pela SEMARH, a maioria dos votantes entendeu que por motivos de segurança apenas pedestres deveriam circular na pista. A decisão seria incorporada ao regimento interno do parque, assinado em 13 de janeiro de 2002 pelo então secretário do meio ambiente, Antônio Barbosa. 
Foram construídas também, trilhas de tijolo inter-travado, que foram assentados em trilhas já existentes de solo compactado pelo pisoteamento, para facilitar o acesso de pedestres, cadeiras de rodas e deficientes visuais. A justificativa para a construção destas trilhas seria, que, sendo feita de peças intertravadas, a permeabilidade da água no solo não estaria comprometida.

Segundo a SEMARH, foram feitos estudos para a adequação das obras propostas, em relação aos materiais que seriam utilizados em sua implementação, com o objetivo mitigar os impactos causados pelas obras no meio natural, buscando utilizar, de forma amena, os materiais considerados mais impactantes.

Ainda assim, as obras geraram bastante controvérsia, tendo sido alvo de diversas reportagens dos jornais do Distrito Federal, com denuncias de que estariam degradando o ecossistema do parque, principalmente porque não estariam sendo fiscalizadas adequadamente. Haveria ainda problemas quanto à forma de trafegar das máquinas dentro do parque, que estaria causando danos ambientais.

A SEMARH alegou que as denúncias teriam motivações políticas, e que viriam principalmente de ex-funcionários da gerência de conservação ambiental do IEMA (Instituto de Ecologia e Meio Ambiente do Distrito Federal) do governo Cristovam Buarque, órgão ligado à Secretaria do Meio Ambiente. Segundo a SEMARH, as obras foram, durante suas várias etapas de andamento, fotografadas e registradas em VHS.

Em dezembro de 2003 começaria a ser formado o conselho gestor do Parque Olhos d' Água. Integram o Conselho: o grupo Escoteiros Bernardo Sayão, a Associação dos Amigos do Parque Nacional de Brasília, a Sociedade Orquidófila de Brasília, Grupo Pegadas, a ONG Patrulha Ecológica, a Polícia Militar, a Administração Regional de Brasília, membros da comunidade, empresas particulares, e prefeituras de superquadras da asa norte de Brasília. 
Em maio de 2004 a Deputada Distrital Arlete Sampaio apresentou projeto de lei na Câmara Distrital propondo a alteração da poligonal do parque, além de sua fiscalização permanente. A deputada denunciou também, que entulhos de obras autorizadas pelo GDF, nas entrequadras SQN 212/213, estariam soterrando as nascentes do parque, e que Áreas de Proteção Permanente, como o Parque Olhos D' Água, têm garantidas, pela lei federal a proteção das nascentes de seus córregos, o que não estaria previsto na legislação do Distrito Federal. As denúncias, com relação à irregularidade das obras, já vinham sendo feitas desde 2001, por membros da comunidade vizinha ao parque, e também por grupos ambientalistas. 


\section{A S.A.P.O}

É impossível não associar a existência do Parque Olhos D’Água à S.A.P.O (Associação dos Amigos Protetores do Parque Olhos D’Água), ONG criada por moradores da SQN 415, com o intuito de mobilizar a comunidade vizinha ao parque, e acionar os mecanismos legais necessários à sua criação.

O engenheiro florestal Fernando Lima, hoje Coordenador de Projeto da Funatura, ONG ambientalista, foi um dos fundadores da S.A.P.O,. e um dos principais articuladores da criação do parque. Lima conheceu a área que formaria o parque ainda no final dos anos 70, e, quando estudante da UnB, e morador da SQN 216, costumava fazer da SQN 415/416 (ao lado da área do parque), uma passagem no caminho da Universidade para casa. Ainda a época, já havera ficado impressionado com a área. "Percebia que ali existia um microclima diferente, um lugar mais úmido, mais agradável".

Após ter entrado para a Secretaria de Meio Ambiente e Recursos Hídricos do Distrito Federal em 1992, foi trabalhar no Núcleo de Manejo de Áreas Protegidas, e depois, designado para o cargo de Gerente de Conservação Ambiental do núcleo responsável pela administração dos parques do Distrito Federal.

Segundo Lima, começou a tornar-se forte na secretaria a idéia de que era necessário implementar de fato os poucos parques ecológicos existentes no DF, que se encontravam em estado de completo abandono. O temor existente na secretaria era que os parques, que justamente por seu estado de abandono haviam tornado-se abrigos para marginais, colônias de alcoólatras e usuários de drogas, fossem um alvo cada vez mais fácil para a especulação imobiliária. 
O raciocínio era que apenas seria possível manter os parques, com o apoio das comunidades residentes ao redor destes. Porém, naquelas circunstâncias, o fato de ter um parque ecológico perto de casa trazia as comunidades mais problemas do que benefícios. Dentro do Parque Ecológico do Guará, aconteciam até "desmanches" de carros. Isto levava as comunidades a preferirem ver as áreas ocupadas por algum empreendimento imobiliário do que a continuar a ter ali um "matagal" abandonado, motivo de temor e insegurança.

Além disso, crescia a preocupação com a necessidade de preservação da vegetação nativa dentro do Distrito Federal. No Plano Piloto a maior parte do Cerrado já havia sido substituído por vegetação exótica, muitas vezes apenas por motivos estéticos.

O próprio Parque da Cidade é muito mais uma área urbana de lazer do que um parque destinado à conservação ambiental, possuindo apenas algumas manchas de Cerrado, e sendo formado, em sua maior parte, por vegetação exótica. Por isso, era necessário não apenas procurar manter os parques ecológicos que já existiam, mas também fomentar a idéia de que o Distrito Federal precisava de mais parques voltados à preservação ambiental.

Neste contexto começou a surgir à idéia da criação do Parque Olhos D’Água e da S.A.P.O. Em 1993 Lima foi procurado, na SEMATEC, por duas moradoras, Maria Celeste ${ }^{3}$ e Marisa de Góes, do bloco "P" da SQN 415, localizado exatamente em frente à área que hoje forma o parque.

Maria Celeste era uma professora de educação física, recém aposentada, que se dispunha a explorar área de mata alta, localizada em frente a sua casa, quando poucos se atreviam a faze-lo. $O$ aspecto abandonado que caracterizava a

\footnotetext{
${ }^{3} \mathrm{O}$ autor do trabalho tentou entrar um contato com Maria Celeste, porém, não obteve retorno. Fernando Lima, utilizado em entrevista como fonte de pesquisa para a reconstituição da história da S.A.P.O, não conseguiu recordar o sobrenome de Maria Celeste.
} 
área, aliado à presença de alguns invasores ainda instalados ali, causava uma má impressão, e despertava receio na comunidade.

Porém, na época, somente enfrentando a mata, era possível ver as nascentes e a lagoa. Maria Celeste vira, e percebera a riqueza de recursos naturais e a beleza cênica do lugar, e começou a considerar a idéia de mobilizar a comunidade e o Poder Público pela criação de um parque naquela área.

Como não dispunha de conhecimentos técnicos, a professora foi buscar em Marisa de Góes, engenheira agrônoma e funcionária da Embrapa, respaldo para sua idéia. As duas então, organizaram, em um final de semana, junto a alguns (poucos) moradores da SQN 415, uma pequena passeata pelo Eixão do Lazer, em que pediam, através de uma faixa, a criação do Parque Olhos D’Água. Por acaso havia a presença de imprensa no Eixão, e a passeata acabou se tornando motivo de uma pequena matéria, publicada por um jornal da cidade.

Sentindo que a matéria havia causado alguma repercussão entre os moradores, principalmente da SQN 415, e que entre estes havia demanda pela presença de um parque ao lado da superquadra, Marisa Celeste e Marisa, decidiram então, ir a SEMATEC, para investigar como poderiam começar a transformar o Parque Olhos D’Água em realidade.

$\mathrm{Na}$ Secretaria, Lima informou às duas moradoras, que a criação de parques era prerrogativa do Poder Legislativo. Sugeriu que procurassem algum deputado, dentro da Câmara Distrital que manifestasse interesse pela causa. O projeto de criação do parque poderia até ser elaborado dentro da SEMATEC, mas era preciso que algum Deputado Distrital se dispusesse a assina-lo, e coloca-lo em votação. 
Assim, o então Deputado Distrital Geraldo Magela foi contatado. Magela possuía em sua história pessoal, estreitas ligações com a SQN 415/416. Entre o final da década de setenta e o início dos anos oitenta, proliferaram em Brasília os Cineclubes. Os Cineclubes eram espaços dedicados a exibição gratuita de filmes de temática geralmente política, social ou contestadora. Funcionavam também como pequenos focos de resistência à ditadura militar.

Magela havia sido um dos coordenadores de um cineclube localizado na SQN 415/416, o Cineclube Olhos D’Água. Naturalmente atraído pela idéia, o próprio Magela acabou elaborando o projeto que propunha a criação do Parque Olhos D’Agua. Aprovado sem grande dificuldade, o Projeto de Lei $n^{\circ}$ 556/93 estabelecia que deveria ser criado na SQN 413/414 o Parque Ecológico Olhos D'Água.

Porém, o projeto aprovado na Câmara Distrital, era um Projeto de Lei Autorizativo (P.A). Ou seja, o projeto autorizava o Poder Executivo a criar o parque, mas efetivamente ainda não criava nada. Neste momento, percebendo a fragilidade da situação e temendo que o projeto ficasse perdido na burocracia do Poder Executivo, Maria Celeste, Marisa de Góes e Fernando Lima decidiram criar a S.A.P.O.

A ONG começou a tomar forma através da participação de alguns moradores da SQN 415 e de amigos dos fundadores, também interessados por questões ambientais, que decidiram integrar a S.A.P.O. Não mais que quatorze pessoas chegaram a integrar ONG, todos moradores da asa norte.

Uma das primeiras ações foi então, a organização de pequenos mutirões para a retirada de lixo da área, que se encontrava bastante poluída. Contando com o auxílio de integrantes da ONG Patrulha Ecológica, e depois, também com a ajuda da Novacap, os membros da S.A.P.O passaram a, nos finais de semana, 
dedicar-se a limpeza da área. A iniciativa deu resultados, e o lixo que existia, pelo menos em áreas mais críticas, acabou sendo em grande parte retirado.

Porém, as campanhas de limpeza da área do parque tinham entre seus objetivos, chamar a atenção dos moradores da vizinhança e mobiliza-los na luta pela implantação do parque. Como isto não ocorreu, e como a maior parte do lixo havia sido atirado ali por moradores da própria vizinhança, um dos integrantes da S.A.P.O, o artista plástico Normando Rodrigues, teve a idéia de, com a aproximação do natal de 1993, construir uma "árvore de natal de lixo" no parque.

O objetivo de Rodrigues era mostrar aos moradores que eles próprios haviam transformado o lugar em uma espécie de "depósito de lixo". Uma árvore de angico caída foi utilizada como "esqueleto", e amarradas a ela os mais diversos tipos de objetos jogados no parque, como: latas de óleo, bonés, penicos e até privadas.

A criatividade de Rodrigues teve repercussão positiva dentro da própria comunidade, e automóveis passavam buzinando, em aprovação a idéia. A "árvore de natal de lixo" acabaria também tornando-se uma tradição dentro do parque. Temáticas, e a cada ano Rodrigues escolhia um tipo de material para a sua obra.

Entre agosto e setembro de 1998, Rodrigues foi diagnosticado com câncer de pulmão. Tendo sido avisado pelos médicos da gravidade de seu caso, manifestou aos colegas o desejo de construir a última "árvore de lixo" no parque. Feita com garrafas descartáveis de refrigerante, a idéia do artista era mostrar que objetos jogados no lixo, também poderiam ser reutilizados, não apenas para reciclagem, mas também para a construção de obras de arte.

Rodrigues ainda conseguiu começar a obra. Usando sementes de "Saboneteira", árvore de vegetação exótica, encontrada no Plano Piloto, o artista 
colocava as sementes dentro das garrafas, e utilizando um pouco de tinta as fazia "girar" pelo seu interior, deixando que as próprias sementes espalhassem a tinta pelas garrafas.

Já bastante debilitado pela doença o artista acabou contando com o auxílio de alunos da Escola Classe da SQN 415, que coletaram garrafas e fizeram sua pintura. Rodrigues ainda teve tempo de ver a obra finalizada, ganhando uma matéria do jornal "Correio Brasiliense", antes de falecer, justamente no dia de natal, em 25 de dezembro de1998.

Foi, porém, a árvore de 1993, que serviu como mote para a divulgação do trabalho realizado pela S.A.P.O na mídia do Distrito Federal. Primeiro foi o "Correio Brasiliense", publicando uma foto e dedicando uma matéria à iniciativa de Rodrigues. Depois, foi a Rede Globo, que dedicou uma matéria, feita para o telejornal DF TV à luta da ONG pela criação do parque. Questionados pelo repórter, a respeito do que seria necessário para a implantação do parque, os membros da ONG, responderam que seria necessário, antes de mais nada o interesse por parte do Poder Executivo, e pediram que o então Secretário do Meio Ambiente e Recursos Hídricos, Newton de Castro, os ouvisse em audiência.

O apelo feito via satélite teve resultado, e Castro foi até a sede da Escola Classe da SQN 415 para uma reunião com os membros da ONG. Questionando a respeito de quais providências poderia tomar para iniciar a implantação do parque, o secretário ouviu dois pedidos: a retirada dos invasores que ainda restavam dentro das dependências do parque, e o cercamento da área.

Segundo Lima, presente à reunião, Castro alegou que nada poderia fazer quanto à primeira solicitação. Porém, prometeu cercar área do parque, entendendo que o cercamento exerceria "pressão psicológica" sobre os invasores, obrigando-os assim a sair da área. 
A promessa foi cumprida, e o parque conheceu assim o primeiro cercamento de sua poligonal, feito com Eucaliptos, por falta de verbas para a realização de um cercamento mais adequado. Foi, porém, apenas no mês de setembro de 1994, já no final de seu mandato, que o então governador Joaquim Roriz assinou o Decreto Lei que criava oficialmente o Parque Ecológico Olhos D' Água.

Com o término do mandato de Roriz, e a chegada de um novo governo ao GDF, os membros da S.A.P.O tinham a esperança de ver o parque definitivamente implementado. A esperança, porém, acabou revelando-se frustrada. Embora nessa época tenha sido construída a sede do parque, poucas outras ações foram realizadas para sua real implementação. O parque chegou a ser inaugurado quatro vezes, porém sem nunca conseguir cativar e atrair a atenção da população.

Seguido às inaugurações, o parque retornava a um estado de abandono. Embora tenha sido lançado durante o governo Cristovam Buarque, o programa "Brasília: Cidade dos Parques", acabou tendo poucas conseqüências positivas para o Parque Olhos D' Água. A verba destinada ao projeto foi diluída entre os vários parques do Distrito Federal, e revelou-se insuficiente para a manutenção adequada da maioria deles.

Segundo Fernando Lima, ainda Gerente de Conservação Ambiental da SEMATEC à época do governo Buarque, foi elaborado dentro da secretaria, um plano de manejo para o parque, semelhante ao que seria implementado pelo governo sucessor em 2001, mas que possuía, entretanto, algumas diferenças em relação a este. Segundo Lima," pensávamos em construir uma pista de cooper, mas não pensávamos em asfalta-la. Também não pensávamos em fazer o calçamento das trilhas".

Ainda durante o governo Cristovam Buarque a S.A.P.O se desfez, encerrando suas atividades. Embora lamente a falta eventos culturais, que 
chegaram a ocorrer no parque, organizados pela S.A.P.O em parceria com o GDF, e a ausência de projetos de educação ambiental no parque, Fernando Lima acredita que o trabalho feito pela ONG teve resultados, e que o parque hoje cumpre a sua função, como Área Protegida, de conservar aqueles ecossistemas, principal objetivo da luta da S.A.P.O. Nas palavras de Lima:

" quando eu ainda sonhava com o parque, quando a realidade ainda não existia, lembro que ás vezes ia dormir, e sonhava mesmo. Via quadras de esporte, via o parque instalado, aquelas coisas vinham durante os sonhos. Na realidade, isso não existe. Existe o que esta lá hoje, e eu acho, que a realidade que está ali, é muito mais interessante que qualquer sonho que nós tenhamos sonhado. O que importa, é que aquela comunidade, e Brasília hoje, têm a sua disposição uma área, que talvez seja a única que ainda comporta algumas fisionomias de Cerrado que já não se encontra mais, principalmente dentro do Plano Piloto". 


\section{Um indicador da relação da comunidade com o Parque Olhos D'Água em 1996}

Pesquisa realizada por Luz, I.R, publicada pelo Laboratório de Psicologia Ambiental da UnB em 1998, serve como base para análise do nível de envolvimento da comunidade local com o parque á época.

A pesquisadora fez uma amostra composta entre quarenta indivíduos, moradores das SQN's 411,412,415 e 416, sendo dez moradores de cada quadra. A coleta de dados foi realizada durante o $1^{\circ}$ semestre de 1996. Aos moradores foi aplicado um questionário contendo oito questões (ANEXO 01), todas com alternativas para os respondentes, exceto por uma que perguntava quem, na opinião dos entrevistados, era beneficiado com a existência do Parque Olhos D’Água.

Dos entrevistados, apenas doze (30\%) afirmavam freqüentar com assiduidade o parque. Quinze moradores da região afirmaram nunca ter ido ao parque. Apenas sete sabiam o ano em que a área havia sido cercada, e apenas treze, o nome correto da S.A.P.O.

Os números mostravam baixo grau de conhecimento e pouco envolvimento da comunidade com o parque. $O$ fato pode ser explicado pela desconfiança e sensação de insegurança que o parque ainda despertava na comunidade. Recém criado, ainda não havia conseguido estabelecer-se como área de lazer, e nem ser reconhecido por aquela comunidade como um lugar que the pertencesse de fato.

Dezessete entrevistados, mais de $40 \%$, afirmavam que a qualidade de vida de sua superquadra não havia melhorado com o cercamento do parque. Esta falta de interesse por parte da própria comunidade, acabava levando a um ciclo vicioso: a comunidade freqüentava pouco o parque, não o reconhecendo como seu. 0 
parque, sendo pouco freqüentado possuía pouca visibilidade e adquiria pouca relevância para o Poder Público, que por sua vez, não mobilizava recursos para sua manutenção e real implementação.

Embora, o parque ainda pouco freqüentado, a consciência a respeito da importância da conservação de seu ecossistema existia entre a população, como se vê a seguir. A última questão proposta por Rodrigues, dava ao entrevistado, a possibilidade de escolher mais de uma alternativa como resposta. Respondendo à proposição: "Você considera o Parque Olhos D’Água":

- "Uma opção de lazer para as crianças".

- "Um lugar agradável para a prática de exercícios físicos".

- "Útil porque evita a criação de invasões, assim, diminuindo a violência".

- "Importante porque ajuda a preservação da vegetação do cerrado e das nascentes".

A quarta alternativa, justamente a que ressaltava a questão ambiental, foi escolhida por trinta respondentes (cerca de $75 \%$ ). A terceira alternativa foi escolhida por dezesseis entrevistados (cerca de 40\%), mostrando que a presença de invasores causava receio em parte considerável da comunidade, temendo que a disparidade social existente entre esta, e os invasores, pudesse colocar em risco sua segurança.

A primeira e segunda alternativas, relativas à utilização do parque como área de lazer e prática de exercícios físicos, foram as que obtiveram o menor número de escolhas, treze e sete, respectivamente. A falta de infra-estrutura e a suposta falta de segurança do parque ainda o mantinham afastado, e não 
considerado como opção de lazer, por grande parte da comunidade no início de 1996. 


\section{Um Indicador da Percepção dos Freqüentadores do Parque em 2001.}

Cinco anos após a pesquisa anterior, outra pesquisa foi feita no Parque Olhos D’Água. Apesar de realizada pelo mesmo laboratório da UnB, não faz menção a pesquisa anterior.

Esta pesquisa realizada por Spehar, Guedes \& Silva, publicada em 2002, capta a percepção dos freqüentadores quanto ao parque no momento que este começava a consolidar-se como área de lazer para os moradores do Distrito Federal, e principalmente da asa norte. Realizada durante o segundo semestre de 2001, a coleta de dados corresponde ao período em qual as obras iniciadas pela SEMARH em 1999, foram oficialmente inauguradas pelo GDF, e em qual o parque ganhou a nova denominação de Parque Ecológico de Uso Múltiplo.

A amostra da pesquisa é de sessenta e um indivíduos, sendo $33 \%$ residindo em superquadras circunvizinhas ao parque $(415,416,214,215$ e 216 norte), 49\% em demais quadras da Asa Norte, e 18\% em outras regiões do Plano Piloto (Sudoeste, Asa Sul e Cruzeiro). A Policia Florestal avaliava que a média de freqüência do parque, nos finais de semana, era de 2.000 pessoas.

Em relação à freqüência dos indivíduos entrevistados ao parque:

- $31,1 \%, 1$ a 2 vezes por semana,

- $21,3 \%, 3$ a 4 vezes por semana,

- $11,5 \%, 5$ ou mais vezes por semana,

- $34,4 \%, 1$ a 2 vezes por mês. 
Em relação à quanto tempo os indivíduos frequentavam o parque, os maiores índices foram: $18 \%$ até um mês e $44,3 \%$ até seis meses, mostrando que parte considerável dos entrevistados havia começado a freqüentar o parque quando este já dispunha de sua nova infra-estrutura.

Os entrevistados também avaliaram aspectos gerais do parque. Dando notas, dentro de uma escala de 1 a 6 , sendo 1 péssimo, 2 ruim, 3 razoável, 4 bom, 5 muito bom e 6 excelente, foram obtidas as seguintes médias:

- Preservação ecológica - 4.48,

- Limpeza - 4.28,

- Estrutura Física - 4.16,

- Sinalização - 4.12,

- Administração - 3.85,

- Duchas - 3.28,

- Bebedouros - 3.09,

- Banheiros - 2.66.

A maioria (68,34\%), avaliou que os principais aspectos a ser melhorados no parque, diziam respeito a sua infra-estrutura (bancos, banheiros, duchas, trilhas) para receber o freqüentador. $O$ aspecto menos lembrado foi a segurança $(2,41 \%)$. Enquanto a infra-estrutura instalada, na 
opinião dos frequentadores, ainda deixava a desejar, o parque já era, porém, considerado um espaço seguro.

Em relação à proposição "você considera o Parque Olhos D'Agua", com cinco opções de escolha, os freqüentadores responderam:

- “Um lugar agradável para praticar exercícios físicos" (34,4\%),

- "Importante para a preservação do Cerrado" (18,9\%),

- “Uma opção de lazer para crianças e adolescentes" (16,7\%),

- "Um lugar para relaxar" (15,6\%),

- "Uma opção de lazer para adultos" (12,2\%),

- "Um ponto de encontro" (2,2\%).

Percebe-se a consolidação do parque, na percepção dos moradores como área propícia à prática de corridas, caminhadas e exercícios físicos, e também atividades de lazer (se consideradas as quatro últimas opções como referentes a alguma forma de lazer, a soma seu porcentual chega a $46,7 \%$ das respostas).

O índice relativamente baixo $(18,9 \%)$ de escolha referente à questão ambiental contrasta com o percentual de entrevistados que afirmaram ter interesse pela preservação ambiental 63,9\%. É necessário ressaltar também, 59\% dos entrevistados mostraram interesse em participar de algum programa de educação ambiental, embora $93,4 \%$ desconhecessem a existência de qualquer programa de educação ambiental ligado ao parque. 
As pesquisadoras entrevistaram também os policiais florestais na sede do parque. Os policiais concordavam com as críticas dos frequentadores relativas a aspectos de infra-estrutura do parque, como estado de conservação e limpeza de banheiros e duchas, porém, queixavam-se do fato de haver uma distância física entre a administração e a sede do parque, sentido-se assim sobrecarregados, por terem que, por vezes, eles próprios realizarem a limpeza destes equipamentos.

Dois pontos, portanto, a serem destacados no trabalho de Spehar, Guedes \& Silva: a completa falta de projetos de educação ambiental que atingissem a população, e o diagnóstico negativo, por parte de funcionários do parque, em relação à sua infra-estrutura administrativa. 


\section{A Situação Atual do Parque Olhos D’Água}

Atualmente o Parque Olhos D’Água está aberto ao público das 7:00 as 19:00, sendo o horário de fechamento prorrogado para as 20:00, durante o horário de verão.O parque está sob responsabilidade da Secretaria de Administração de Parques e Unidades de Conservação do Distrito Federal. A segurança é feita por um efetivo de 14 policiais, todos da Companhia de Polícia Ambiental do Distrito Federal. Existe segurança no parque 24 horas por dia.

Segundo policial entrevistado pelo autor do trabalho, o parque recebe em média, de 3.500 a 4.000 visitantes por final de semana. O cálculo é baseado na observação e experiência do policial, que exerce a função no parque há dois anos, já que não existe um controle efetivo do número de freqüentadores do parque. No dia da entrevista, realizada ao final de uma tarde nublada de sexta-feira no início do mês de julho, o policial calculava que aproximadamente quinhentas pessoas já haviam visitado o parque.

A entrevista foi realizada na sede do parque. Durante o período de aproximadamente uma hora em que o autor do trabalho permaneceu no parque, havia lá cinco policiais. Dentro da sede, somente o entrevistado e o autor do trabalho.

Em relação à segurança do parque, segundo o entrevistado não existe uma rotina de rondas com horários estabelecidos para os policiais. Os maiores problemas em relação a atos de vandalismo dentro do parque são causados principalmente por pichadores. Algumas placas de aviso encontram-se poluídas por pichações (ANEXO 02 foto 16). Os pichadores jamais foram identificados.

Segundo o entrevistado, a presença de usuários de drogas já foi mais freqüente, sendo atualmente pouco comum. O policial recorda-se apenas de um 
caso recente, um usuário flagrado fumando um cigarro de maconha em um dos bancos do parque, em uma manhã de domingo.

Em relação a outros problemas causados por freqüentadores, existem casos (raros) de pequenos tumultos causados por brigas e discussões entre familiares, que já exigiram intervenção por parte dos policiais. Houve também, o caso de um usuário que praticava atos obscenos dentro do parque, tendo sido denunciado e descrito por outros freqüentadores, sendo posteriormente identificado pela Polícia Ambiental.

O maior trabalho dos policiais, entretanto, é com a presença de ciclistas, que insistem em entrar no parque para praticar o esporte. A prática do ciclismo é proibida pelo regulamento interno do Parque Olhos D’Água desde 2001.Segundo o policial entrevistado, quando flagrado o ciclista, é feita uma abordagem com o intuito de explicar ao mesmo o regulamento do parque e solicitar sua retirada do local.

Como a maioria alega justamente desconhecer o regulamento, é solicitado pelos policias o número da carteira de identidade, telefone e endereço do ciclista. Em caso de reincidência a justificativa não é mais considerada, e providências legais podem ser tomadas. O regulamento interno do parque proíbe apenas o uso de bicicletas e similares, sendo permitido o uso de equipamentos como patinetes e patins. A entrada de animais de estimação também é proibida pelo regulamento interno do parque

O fator mais preocupante, relativo à segurança, entretanto, é a constância com que ocorrem arrombamentos de veículos nas superquadras circunvizinhas ao parque. Usuários do parque já foram vitimas deste tipo de crime. Como seu estacionamento comporta um número muito reduzido de veículos, a maioria dos freqüentadores que se dirige ao parque de automóvel utiliza para estacionamento justamente as vagas disponíveis nestas superquadras. 
Quanto à infra-estrutura, chama a atenção, a precariedade da sede do Parque Olhos D' Água. Pequeno, o espaço serve de abrigo tanto para a Polícia Ambiental quanto para a administração do parque. Dentro da sede a estrutura de trabalho oferecida tanto aos policiais, quanto à administração é quase nenhuma. Não há computadores, aparelhos de fax e sequer aparelhos telefônicos. O único aparelho telefônico fixo disponível no parque é um "orelhão", localizado justamente em frente à sede.

Existe também insatisfação por parte dos policiais em dividir a sede com a administração. Segundo o policial entrevistado os policiais gostariam de contar com um posto próprio para a Polícia Ambiental, já que consideram-se muito expostos, pelo fato da sede servir como abrigo para seus armamentos, e ser de fácil acesso a qualquer usuário do parque.

As limitações quanto às condições adequadas de gestão de Áreas Protegidas são aliás comuns em países em desenvolvimento. Estudo realizado em 1995 por Amend \& Amend in Morsello, 2000, p. 204, investigava a percepção de funcionários de parques da América do Sul a respeito das principais ameaças aos parques, através da questão: "Quais são os três principais problemas de seu parque?". De vinte problemas apontados pelos funcionários, como resultado da pesquisa, ao menos sete, estavam diretamente ligados a questões estruturais e administrativas como pode ser verificado na tabela da página seguinte. 
Principais Ameaças aos Parques da América do Sul

\begin{tabular}{|l|c|}
\hline \multicolumn{1}{|c|}{ Ameaças } & $\begin{array}{c}\text { \% de parques que apresentam o problema } \\
\text { (n=148) }\end{array}$ \\
\hline Falta de pessoal qualificado & $27,0 \%$ \\
\hline Planejamento deficiente do manejo do parque & $20,3 \%$ \\
\hline Limites do parque inadequados ou mal definidos & $16,2 \%$ \\
\hline Falta de controle e vigilância & $16,2 \%$ \\
\hline Falta de recursos financeiros & $11,5 \%$ \\
\hline Falta de instalações físicas e infra-estrutura & $11,5 \%$ \\
\hline Falta de apoio político institucional & $6,1 \%$ \\
\hline
\end{tabular}

Fonte: Amend \& Amend

No caso do Parque Olhos D’Água, as eventuais limitações quanto a recursos humanos e financeiros de sua administração, não chegam a prejudicar , ainda, a qualidade da experiência do freqüentador. A pista e as trilhas encontramse limpas e bem conservadas, sendo raro encontrar alguma poluição causada por usuários.

Embora exista apenas um funcionário do GDF encarregado da limpeza e manutenção dos equipamentos do parque, os banheiros e bebedouros encontramencontram-se em boas condições de uso, embora o policial ambiental entrevistado tenha relatado que já tenha sido necessário os próprios policiais comprarem papel higiênico para os banheiros dos usuários, por falta de reposição por parte do GDF. O único sinal visível de degradação nos equipamentos do parque é a inclinação de uma parte da cerca (ANEXO 02 foto 17) ao lado da SQN 415, devido a rachaduras em sua base, causadas pela ação do tempo.

O estado de conservação dos recursos naturais é, em geral bom, embora existam sinais de poluição perto da nascente, localizada acima da lagoa do sapo. O autor do trabalho chegou a encontrar pedaços de azulejo dentro da própria nascente (ANEXO 02 foto 18). 
Embora exista freqüência durante a semana, principalmente por parte de jovens que utilizam os aparelhos de musculação, idosos que utilizam a pista para caminhadas, crianças acompanhadas por parentes, empregadas domésticas e babás, "andando" de patins ou patinetes, ou brincando no parque infantil, e usuários praticando atividades físicas, é durante os finais de semana que o Parque Olhos D'Água conhece sua maior demanda, quando nota-se um grande número de usuários praticando cooper e caminhadas.

Segundo Godfrey-Smith, 1980 in Wearing \& Neil 2000, as justificativas para a conservação da natureza poderiam ser divididas em principalmente quatro:

- Estética/Espiritual - natureza valorizada por oferecer deleite estético e despertar espiritual.

- Biológica/Biodiversidade - natureza valorizada por seu estoque de diversidade genética.

- Científica - natureza valorizada para pesquisa científica.

- Atlética - natureza valorizada para o turismo e recreação.

Embora a visão moderna de conservação ambiental seja holística, não desassociando o homem da natureza, e não atribuindo a ela, um valor utilitário, pode-se considerar que as justificativas classificadas por Godfrey-Smith são ainda freqüentemente utilizadas como argumentos para questões relativas a conservação ambiental.

A justificativa da natureza valorizada como cenário para atividades turísticas e recreativas, classificado também como argumento "ginásio de esportes" pelo autor, parece ser a que mais se adequa à situação atual do Parque Olhos D' 
Água. Sua demanda crescente nos últimos anos deve-se principalmente ao fato da área oferecer justamente infra-estrutura adequada a pratica de atividades de lazer como cooper e caminhadas.

A prática destas atividades, como forma de alívio do estresse urbano, relaxamento, cuidado físico ou motivações estéticas, são as mais visíveis dentro do Parque Olhos D’Água. Segundo Camargo, 1986, p.12:

"o mais correto seria dizer que, em toda escolha de lazer, existe o princípio da busca do prazer, mesmo que a atividade inicie com um esforço, para se obter o relaxamento agradável ou a sensação posterior de estar em boa forma".

Assim, à medida que se torna um cenário ideal para a prática de atividades de lazer que estão inseridas dentro do cotidiano de parte considerável da população urbana, o parque adquire um novo status. Uma área que transmite sensação de segurança, apresenta beleza cênica, e é de fácil acesso, como é o caso do Parque Olhos D’Água, passa a ser portanto amplamente valorizada pela população residente em seu entorno e proximidades.

Há ainda a questão da valorização econômica e a que a região em que o parque localiza-se foi submetida nos últimos anos, e que pode ser avaliada pelos imóveis recém erguidos nas 213 e 214 norte. Prédios sofisticados, apartamentos de alto valor financeiro, a promoção da venda destes imóveis passa pelo privilégio de se ter um parque a poucos metros da residência. "Venha morar em frente ao Parque Olhos D’Água", é o slogan utilizado para promoção de um imóvel localizado na 214 Norte.

Há, entretanto , uma questão que permanece pouco explorada, e que seria fundamental, para que o parque fosse também um espaço público dedicado ao exercício da cidadania: seu potencial como instrumento de sensibilização e educação ambiental. 
A maior parte da vegetação hoje encontrada no Plano Piloto de Brasília é exótica, tendo substituído, devido a ações antrópicas, o Cerrado nativo. Dentro do Parque Olhos D’Água, encontra-se também vegetação exótica, mas encontramse, sobretudo, fisionomias de Cerrado que são hoje raras dentro do Distrito Federal. O fato de existirem, talvez somente no Parque Olhos D' Água, estas fisionomias de vegetação nativa, já justificaria o potencial do parque como cenário para a realização de projetos de educação ambiental.

Embora a utilização da área como espaço público de lazer fosse um dos objetivos da criação do parque, e tenha aspectos positivos, por possibilitar que a população tenha acesso a uma área agradável e que apresenta beleza cênica, é preciso ressaltar que o próprio GDF colocava, em documentos da SEMARH, um dos propósitos de criação do parque como sendo a possibilidade de desenvolver ali projetos da educação ambiental.

Seria inclusive, uma maneira de otimizar o potencial de utilização do parque, fazendo com que parte mais abrangente da população do Distrito Federal se beneficiasse com a existência do parque, e não apenas sua comunidade circunvizinha.

É preciso considerar, como exemplo, a possibilidade de oferecer a alunos de $1^{\circ}$ e $2^{\circ}$ graus de escolas do Distrito Federal, a oportunidade de vivenciar in Ioco, o aprendizado obtido dentro de sala de aula. Segundo Ferreira \& Coutinho, 2000, p.174:

" a experiência do estudo do meio tem o potencial de transformar de tal maneira o aluno, que torna o trabalho do educador muito mais gratificante, possibilitando que este se coloque como um medidor do processo de aprendizagem, e não como um mero reprodutor do conhecimento humano acumulado. Estas situações são criadas a partir da percepção do ambiente, da conscientização sobre as ameaças ao equilíbrio ambiental, e da responsabilidade de cada um, como seres vivos integrantes deste mesmo ambiente." 
A visitação a um Parque Ecológico, como o Olhos D’Água, pode, portanto, também ser considerada, como oportunidade de se agregar valores importantes á formação dos cidadãos, se entendida a educação ambiental como parte do processo de educação cívica, e fundamental para o próprio exercício da cidadania. 


\section{Conclusão}

Próximo de completar dez anos de existência oficial, o Parque Ecológico de Uso Múltiplo Olhos D'Água possui um histórico representativo das por vezes conturbadas Políticas Públicas, seja em nível municipal, estadual ou federal, que regem a questão de Áreas Protegida no Brasil, tendo sido inaugurado, e depois reinaugurado diversas vezes, até que contasse realmente com infra-estrutura adequada para tornar-se um espaço público freqüentado pela população.

Pode-se dizer que o Olhos D’Água apenas ganhou realmente status de parque, a partir de 2001, com a instalação de sua nova infra-estrutura, e que a frequência, e visitação da comunidade tenha contribuição decisiva para o estreitamento de seus vínculos com a área.

Seu processo de criação, a partir da iniciativa de um pequeno grupo de cidadãos organizados através de uma ONG, é também exemplar quanto à capacidade de mobilização da sociedade civil, e de como esta pode exercer sua influência, de maneira pró-ativa junto ao Poder Público.

A ONG, no caso a S.A.P.O, foi desfeita, porém, ainda é necessária a participação da sociedade civil e da comunidade em relação a gestão do parque, através de cobranças e sugestões de melhorias para sua administração, ou até mesmo partindo para a ação direta, como angariando recursos financeiros para a manutenção do parque, quando o Poder Público mostra-se lento ou inapto para liberação de verbas para a resolução de problemas que exijam ações urgentes.

Quanto ao Poder Público, aliás, é preciso ressaltar que, embora sejam louváveis iniciativas governamentais que incentivem a criação de Áreas Protegidas, como aconteceu no Distrito Federal, principalmente com a proliferação de Parques Ecológicos nos últimos anos, é preciso lembrar que a questão 
ambiental envolve outros aspectos que não apenas a gestão destas áreas. Segundo Yázigi, 2000, p. 137:

" eis que de repente, o dito ecoturismo virou moda, tanto quanto fonte de votos. Desde então inúmeros prefeitos e governadores deram para inaugurar "parques ecológicos" (que antes existiam, mas eram simplesmente chamados de parques municipais) e vender cartões postais da natureza em seus territórios. Isto no entender deles, os qualificaria como "preservacionistas". Mas por outro lado, incapazes ou impotentes ou até de propósito, deixam tudo acontecer. Loteamentos sem as exigências técnicas do preservacionismo, degradação da paisagem pela ausência de planps de obra adequados, erosões, modos de produção impunes (agricultura, ,indústria...), despejos de restos químicos industriais nos rios, despejo de esgotos, zoneamentos absurdos, educação ambiental limitada a comportamentos pessoais,etc".

É preciso, portanto, que haja conscientização por parte da população, que passa pelo conhecimento e aprendizado a respeito dos ecossistemas de sua região, e a respeito de como suas ações diárias trazem impactos para a sustentabilidade do parque, e do próprio meio urbano, ou seja, educação ambiental, e isto pode e deve ser feito, em lugares com o Parque Olhos D'Água.

Porém, é igualmente importante, que esta conscientização atinja o Poder Público através de uma coerência em suas atitudes, que contemple a questão ambiental em outros níveis, que não apenas o relativo a gestão de Áreas Protegidas. 
11. Referencial Bibliográfico

BARROS, Maria Isabel Amando \& DINES, Milton. Mínimo impacto em áreas naturais: uma mudança de atitude,p.47 a 84 in, Serrano, Célia (org). A educação pelas pedras: ecoturismo e educação ambiental. São Paulo: EdChronos, 2000, 190 páginas.

BRASIL, Lei n 9.985 de 18 de junho de 2000.

Regulamenta o art.225, $\S 1^{\circ}$, incisos I,II,III e IV da Constituição Federal, institui o Sistema Nacional de Unidades de Conservação da Natureza e dá outras providências.Senado Federal. Brasília, 18 de junho de 2000.

CAMARGO, Luiz .Lima Camargo. O que é lazer. São Paulo: Ed Brasiliense, 1986.

CORREIO BRASILIENSE. Disponível em www.correioweb.com.br. Acessado em maio de 2004 .

COSTA, JOSÉ Pedro Oliveira. Áreas Protegidas no Brasil. Disponível em: www.mma.gov.br/port/sbf/dap/costa

COUTINHO, Maria do Carmo Barêa \& FERREIRA, Luiz Fernando. Educação ambiental em estudos do meio: a experiência da Bioma Educação Ambiental p.171 a 187 in, Serrano, Célia (org): A educação pelas pedras: ecoturismo e educação ambiental. São Paulo: Ed Chronos, 2000,190 páginas. 
D’Água. Secretaria do Meio Ambiente e Recursos Hídricos, Instituto de Ecologia e Meio Ambiente: Programa Parques Para o Povo, 1998.

IBAMA: banco de dados. Disponível em www.ibama.gov.br. Acessado em 23 de maio de 2004.

IUCN (The World Conservation Union). Disponível em www.iucn.org. Acessado em 2 de junho de 2004.

LIMA, Simone Cruz \& MACHADO, Elizabeth. Projeto de paisagismo do Parque Urbano de Olhos D'Água. Companhia Urbanizadora da Nova Capital do Brasil (Novacap). Sem Data.

LUZ, Iza Rodrigues. Nível de informação e grau de valorização do parque olhos d'água entre moradores de quadras circunvizinhas. Instituto de Psicologia/Universidade de Brasília. Textos do Laboratório de Psicologia Ambiental, volume 05, № 08,1998.

MINISTÉRIO DO MEIO AMBIENTE DO BRASIL.: banco de dados. Disponível em www.mma.gov.br. Acessado em 29 de maio de 2004

MORSELLO, Carla. Áreas protegidas públicas e privadas: seleção e manejo. São Paulo: Ed Fapesp, 2001.

NEIL, John \& WEARING, Stheven. Ecoturismo: impactos, potencialidades e Possibilidades. Barueri,SP: Ed Manole Ltda, 2000, 256 páginas. SECRETARIA DO MEIO AMBIENTE DO ESTADO SÃO DE SÃO PAULO. 
Diretrizes para uma política estadual de ecoturismo: proposta. São Paulo:

Ed SMA-Ceam, Unicamp-nepam,1997.

SEMARH ( Secretária do Meio Ambiente e Recursos Hídricos do Distrito Federal).

Disponível em:www.semarh.df.gov. Acessado em 20 de maio de 2004.

SPEHAR, Mariana, GUEDES, Luiza A. Miguel \& DA SILVA, Manuella Costa

Percepção dos usuários do parque ecológico olhos d'água. Instituto de

Psicologia/Universidade de Brasília. Textos do Laboratório de Psicologia

Ambiental, $\mathrm{N}^{\circ} 05,2002$.

YÁZIGI, Eduardo. Turismo: uma esperança condicional. São Paulo, SP: Ed

Global Ltda, 2000, 190 páginas.

WWF BRASIL. Manual de ecoturismo de base comunitária: ferramentas para um planejamento sustentável. Miltraud Sílvia (org). Brasília, DF, 2003, 453 páginas. 
Anexo 01

Questionário aplicado por Rodrigues, IR aos moradores das superquadras 411,412,415,416 norte,.durante o primeiro semestre de 1996.

1) Qual a área ocupada pelo Parque Olhos D’Água?

a) Quadra 414 norte

b) Quadras 213 e 214 norte

C) Quadra 413 e 414 norte

d) Quadra 413 norte

2) Em que ano foi cercada a área do parque olhos d'água?
a) 1993
b) 1994
C) 1996
d) não sei

3) Quando foi inaugurada a sede do parque olhos d'água?
a) janeiro/95
b) setembro/95
c) maio/96
d) não sei

4) Você sabe qual é o nome da associação de moradores que trabalha pelo parque?
a) Associação dos amigos do parque olhos d'água
b) Associação dos moradores amigos do parque olhos d água 
c) Socidade dos amigos do parque olhos d água

d) não sei

5) Depois que cercaram o parque melhorou a qualidade de vida da sua quadra.
a) muito
b) razoavelmente
c) um pouco
d) não

6) Quantas vezes você visitou o parque olhos d'água?
a) uma vez
b) algumas vezes
c) várias vezes
d) nenhuma vez

7) Quem é beneficiado com a existência do parque olhos d'água?

8) Você considera o parque olhos d'água:
a) uma opção de lazer para as crianças;
b) um lugar agradável para a prática de exercícios físicos;
c) útil porque evita a criação de invasões, assim, diminuindo a violência;
d) Importante porque ajuda a preservação da vegetação do cerrado e das nascentes.

e) outro, qual? 